\title{
原著論文
}

西岡智秀, 南 清和

\section{Localized ridge augmentation with chin grafts}

Tomohide Nishioka, Kiyokazu Minami

There are some different techniques recently developed for improving abnormal from of alveolar ridge where the prosthetic treatment is needed. The grafting of great amount of tissue is necessary in type II and type III case of (Seivert) classification for correcting the defect. Autogenous bone is reported as the best choice for grafting. In fact the amount of bone available from donor site is limited. Mentle area of oral cavity is considered to be the best site for donating bone by its easily approach character during operation. Ridge augmentation with autogenous bone taken from mental area to correct from of alveolar ridge in maxillary anterior edentulous case will be reported.

Key words： 遊離歯肉移植 free gingival graft, ベニヤグラフト veneer graft, 自家骨 autogenous bone, 静脈内鎮静法 intravenous sedation, オトガイ部 chin

\section{緒 言}

補経前処置として, 部分欠損部の歯槽堤の不正形態を改 善させるため, 様々な術式が考案されている1-6)が, Type II およびType III（Seibertの分類）の不正形態の改善には, より大きな組織の移植が必要となる. 現在のところ, 自家 骨は最も有効なグラフトマテリアルとして利用されている が，採取できる量に限界がある。オトガイ部は口腔内で最 も大量に採取できる部位であり, 操作性もよく, アプロー チしやすい. 今回, 上顎前歯部における歯槽堤不正形態 (Type III) に対して, オトガイ自家骨を利用し, 歯槽堤の 増大が図れたので報告する。

\section{症 例}

患 者: 55 歳, 女性.

初診: 平成 11 年 3 月 8 日.

主 訴: 3 部の腫脹, 疼痛.

既往歴：特記すべき事項なし。

現 症：約 3 年前に上顎前歯部ブリッジを装着するが, たびたび 3 部の腫脹を繰り返し, 昨日, 同部の拍動痛と㚘

ミナミ歯科クリニック

Minami Dental Clinic
部腫脹を認めたため来院（図 1,2）.

\section{方 法}

\section{1. 術式の概要}

3 部の消炎処置後, 原因の除去と炎症のコントロールを 目的として，3」の抜歯と右上印歯部の Open flap curettage を 行う. 2 か月後にボーングラフトを行うための前処置とし て角化組織の獲得をするために, 1 回目の遊離歯肉移植を 行う。4か月後にオトガイ部より採取した骨を用いて，骨 移植を行う。この際, 静脈内鎮静法を併用する.さらに, 4 か月後に口腔前庭拡張, 欠損部の幅の増加, 角化組織の 獲得のため 2 回目の遊離歯肉移植を行う。

\section{2. 治療経過}

\section{1）初期治療}

初診時に拉いて，3」は根尖まで骨吸収が及んでおり，保 存不可能と思われ抜歯となる. 抜歯後 2 か月の時点で, 同 部顎堤は水平的, 垂直的にも著しい顎堤の欠損を認めた (図 3).

\section{2) 1 回目の遊離歯肉移植}

欠損部にボーングラフトを行うための軟組織獲得のため に，両側口蓋部より遊離歯肉移植を行った (図 4,5). 角 

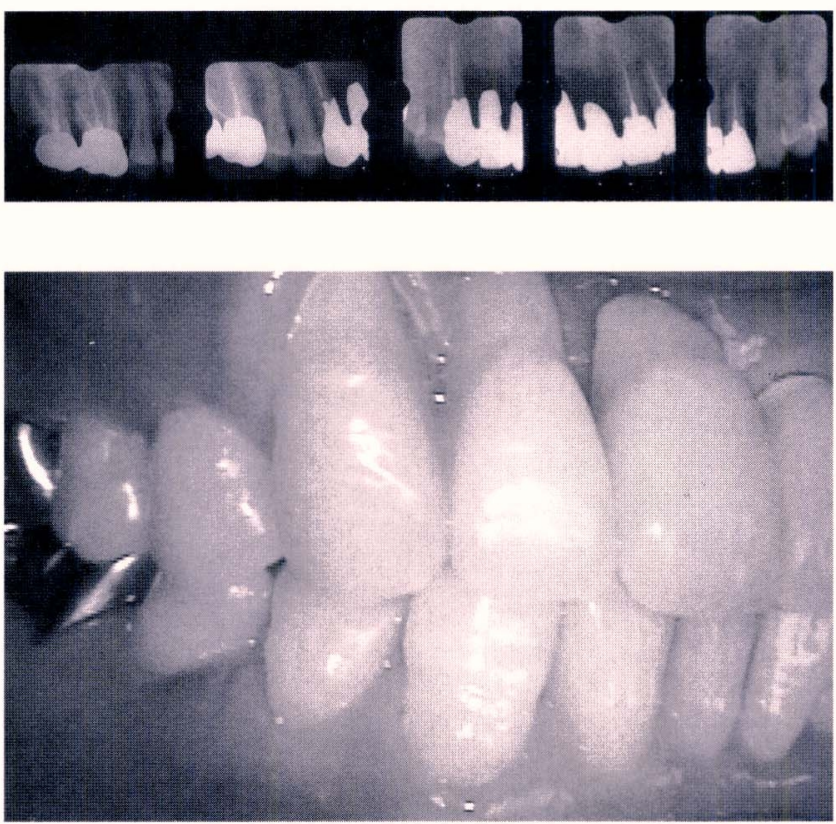

図2 初診時

3 部は保存不可能なため,やむなく 3 †2 のブリッジを除去す ることになる. また, ポンティック部は角化組織がまったくな く, ブラッシング時の疼痛も訴えていた

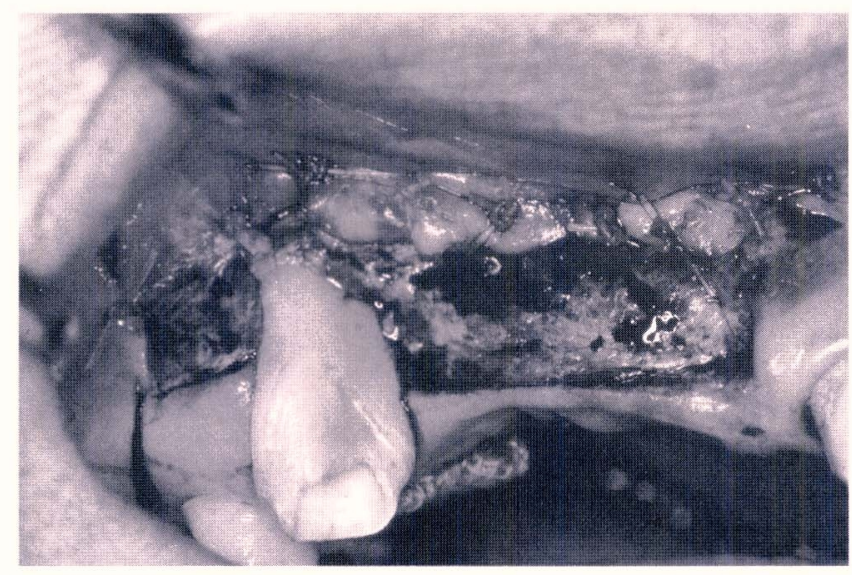

図4 部分層弁にて剥離

吸収性縫合糸にて根尖側に固定したところ

化組織の獲得，軟組織による歯槽堤の幅の増加が認められ た(図6).

\section{3）骨移植}

長時間の手術や，恐怖心の強い患者などの手術では，患 者の精神的・身体的苦痛を考虑し，当院では麻酔科の専門 医とともに静脈内鎮静法を併用している。供給側である才 トガイ部は，デンタル拈よびオルソパントモX線写真にて オトガイ孔の位置，菌根の長さを計測し，右側はカーバイ トバーにてブロック状に，左側は直径 $10 \mathrm{~mm}$ のトレフィン バーにて採取した（図７）。採取した骨は骨細胞の保存の
図 1 初診時デンタルX線写真

3 部の根尖部に及乃゙骨吸収。隣在歯にも波及している

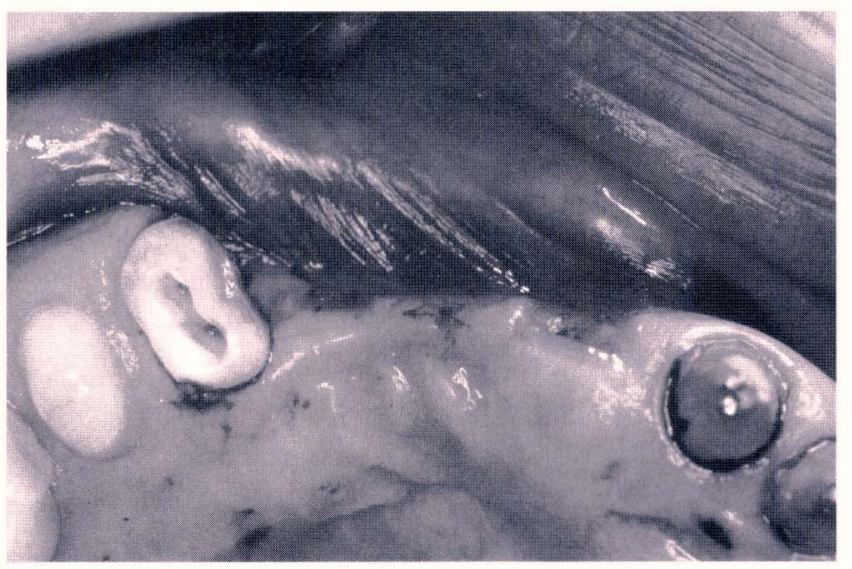

図3 抜歯2か月後の咬合面観 著しい顎堤の欠損が認められ, また, 可動粘膜が歯槽頂付近に まで達している. なお, 外科処置後, 4山は歯蹎炎のため麻抜と なる

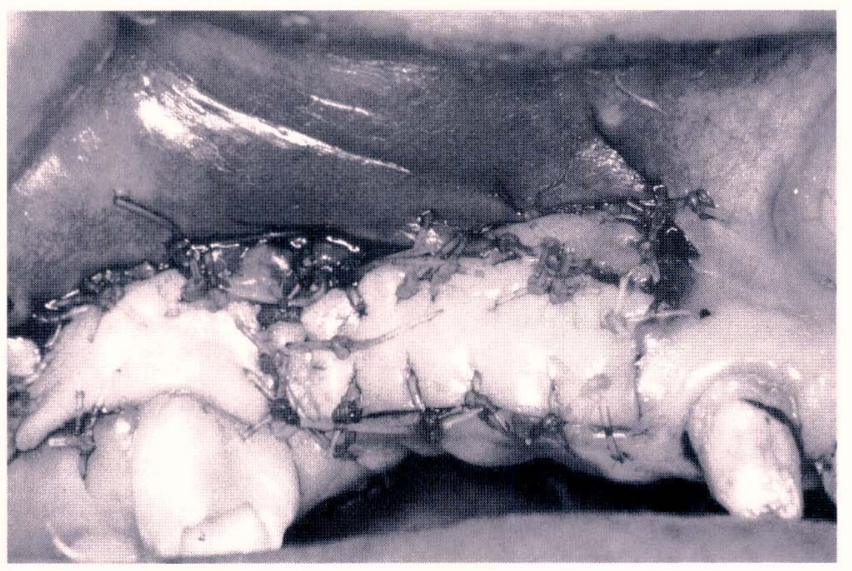

図5 両側口蓋部より採取した遊離歯肉を2片移植したところ

ために血液に浸しておく。需要側の切開線は口蓋側寄りに 水平切開を, 縦切開は正中部に扑いて歯間乳頭を避けて欠 損側寄りと，4」の遠心隅角部にそれぞれ行い，全層弁にて 剥離した。既存の皮質骨を穿孔させた後，ブロック状に採 取した骨をチタン製のピンにて久損部顎堤唇側にベニヤグ ラフトを行った。爷の周囲にトレフィンバーで採取した骨 を粉砕し，移植した（図 8)。このとき，4 远心根面付近 も粉砕骨が覆うようにした。縫合は減張切開を行い, テン ションフリーとする（図9）が，ここで1回目の歯肉移植 が粘膜の操作を容易にする（図 10,11）. 


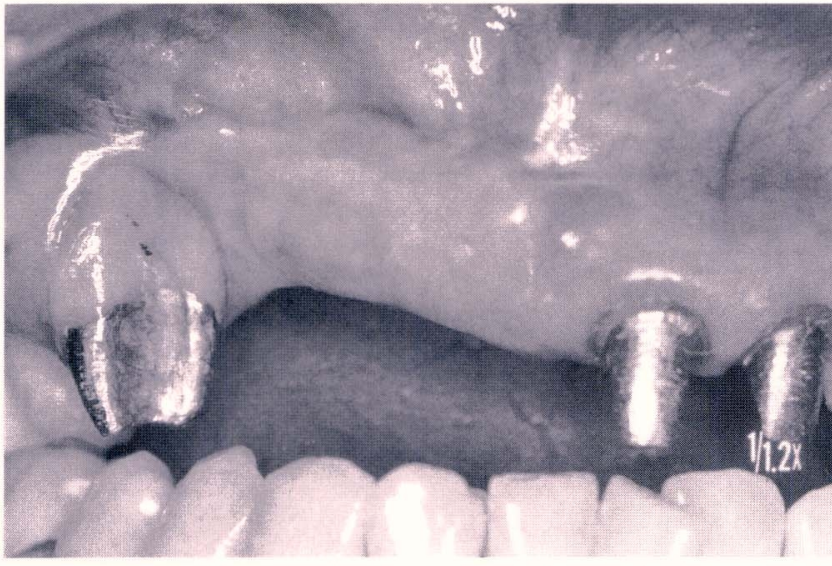

図 6 歯肉移植 2 か月後

十分な角化組織が得られている. 4 の近心部は血液供給量な どの問題により，移植片が一部脱落した

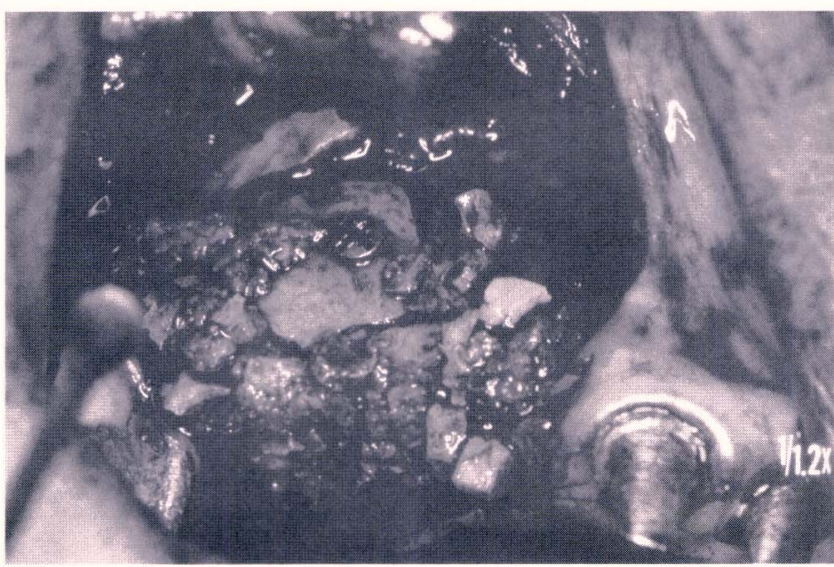

図 8 ベニヤグラフト時

既存の皮質骨を穿孔させて出血を促進させた後, ブロック骨の 適合を確認しながら回転を起こさないように2 本のピンで固 定した．その周りに粉砕骨を移植した

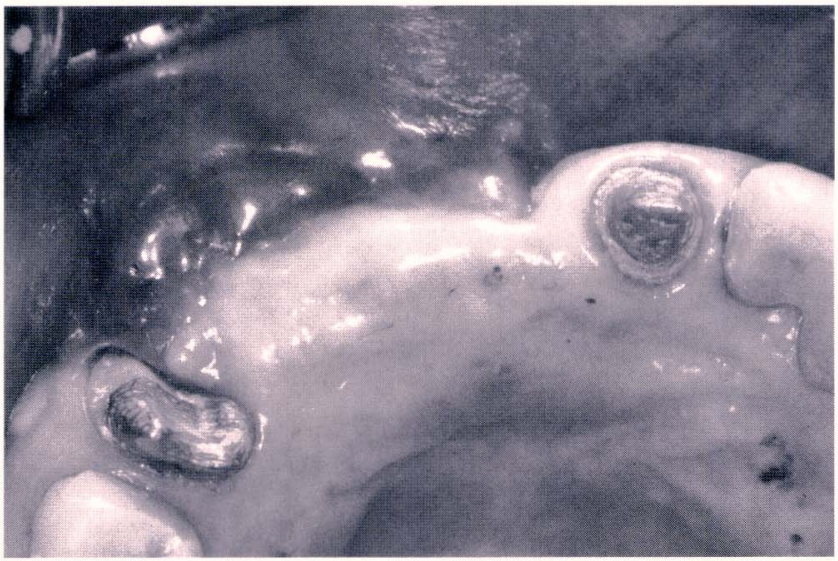

図 10 骨移植 4 か月後の咬合面観

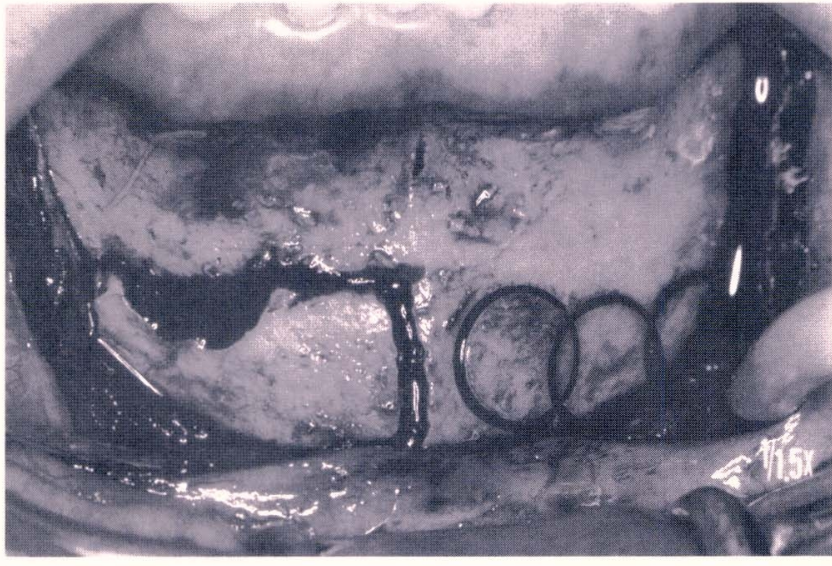

図 7 骨採取時のアウトライン

右側はカーバイトバー, 左側は直径 $10 \mathrm{~mm}$ のトレフィンバー にて採取した. 了部の根尖を避けるため, 凹となる. 正中部は 治癒の促進, オトガイ部の陥没を防ぐために残した

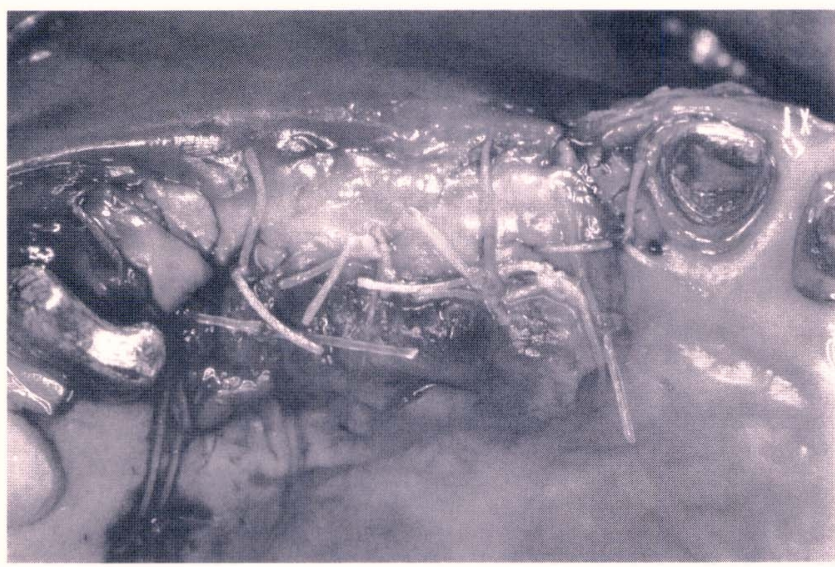

図9 テンションフリーにて縫合

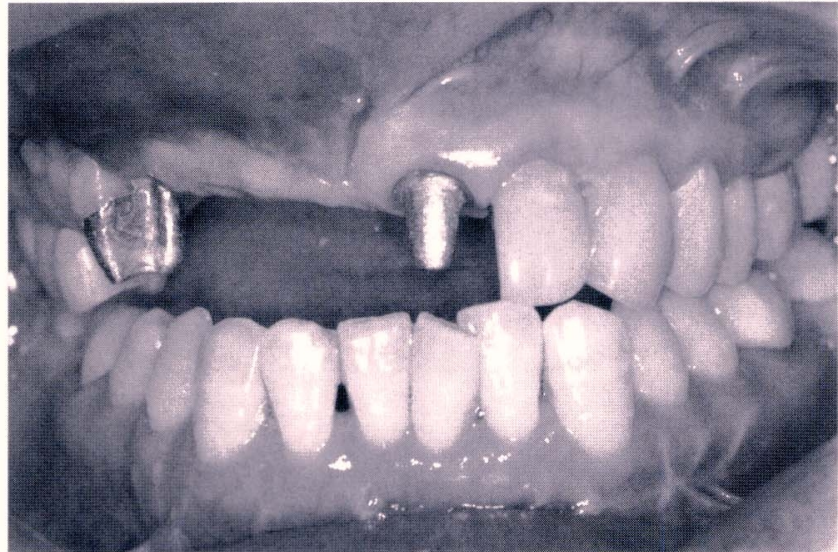

図 11 骨移植 4 か月後の正面観

歯肉レベルが調和してきているのがわかる，4|のマージン ラインを覆っており，垂直的にも著しい造成が確認できる 


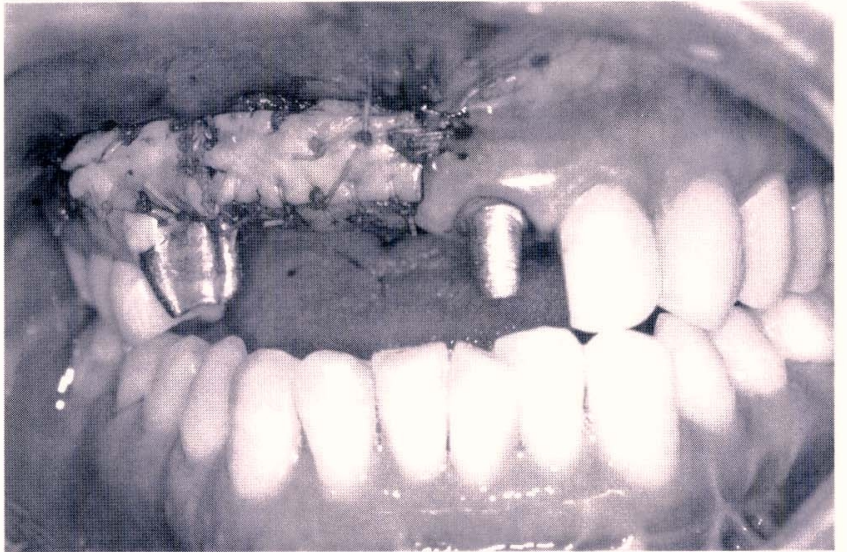

図 122 回目の遊離歯肉移植

口腔前庭拡張と更なるボリュームの増加を目的として，1 回 目と同様に歯肉移植を行った

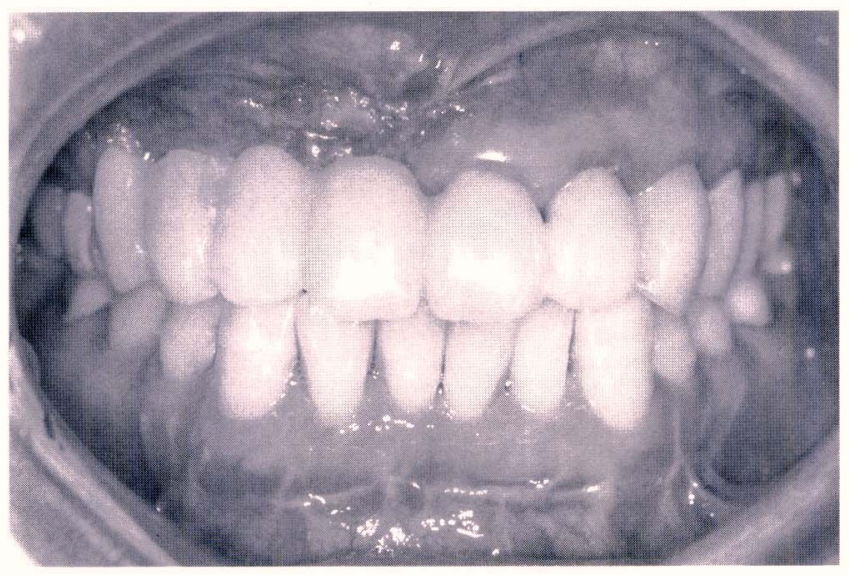

図 14 術後プロビジョナル・レストレーションのポンティック部の 修正

ポンティックの歯肉部分を除去し，組織の治癒を経過観察し ているところ．全体的なバランスがとれている

\section{4） 2 回目の遊離歯肉移植}

口腔前庭の拡張，角化組織の獲得のために1回目と同じ く, 両側口蓋組織から遊離歯肉移植を行った（図 12).

\section{結 果}

術前に比べ，水平的にも垂直的にも著しい㐘槽堤の増大 が認められた（図 13, 14）。

骨移植を行うことにより，隣在歯においてもレントゲン 的に骨の再生が認められた（図 15).

\section{考 察}

今回，骨移植から約 5 か月目までの症例を報告した。移 植骨の吸収率を見込んで，なるべく多くの組織を獲得する

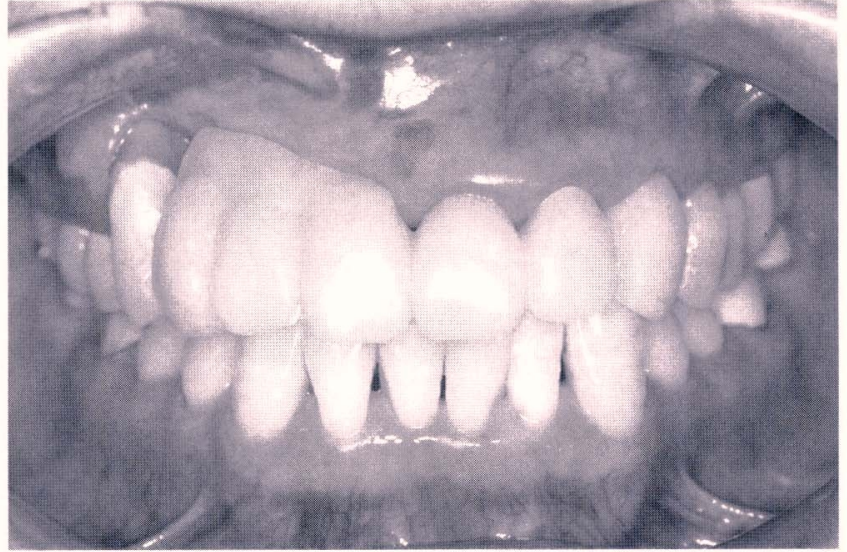

図 13 術前のプロビジョナル・レストレーション

術前では歯肉付きのプロビジョナル・レストレーションで確 認し，どれくらいの造成が必要かおおよその把握をしておく

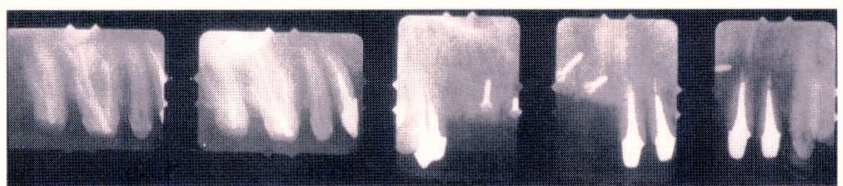

図 15 術後のデンタルX線写真

2本のピンにて移植骨が確実に固定されている。 また４４の 近心も初診時に比べ骨再生が認められる

には，それを覆うだけの軟組織が必要となるため，前処置 としての遊離柬肉移植は必須であると考えた。オトガイ部 からの骨採取は, カーバイトバーにてブロック状に採取し たものと, 直径 $10 \mathrm{~mm}$ のトレフィンバーで採取した骨を粉 砕状にしたものとに分けた。通法ではブロック骨はできる だけ皮質骨十海綿骨で採取するが, 外科的な侵襲を考慮し， 海綿骨内 2 ～ $3 \mathrm{~mm}$ にとと奴。そして，ブロック骨の固 定にはチタン製のピンを使用した。

本症例では組織の侵襲，ピン除去時の破折などを避ける ため，除去せずに経過観察中である。また，外科処置の回 数が必然的に多くなるため，あらかじめ患者にインフォー ムドコンセントの確立をしておくことや，長時間の手術が 予想される場合などは患者の肉体的・精神的苦痛を和らげ る手段の一つとして静脈内鎮静法を併用することが必要と 思われる。

今回の術式では目的とする量の組織は回復できたが，移 植骨の保護の点から考えると GBR 法7.8) も適応と考えられ る。しかし, 血液供給量, 膜の露出, 感染のリスクを考慮 するとGBRをしないことのほうが安全である、GBRしな くとも，ベニヤグラフトした骨が骨膜テントの支柱となり スペースメーキング的な役割を果たし，粉砕骨にて死腔を 
埋める形となり, 骨再生の橋渡しの役割をする(骨増殖能) ことや，既存の皮質骨をパーフォレーションさせ，成長分 化促進因子である Growth Factorなどを活性化させ（骨伝導 能), それらの外層には骨膜（豊富な骨芽細胞）で覆われ ていることにより, 臨床的に許容範囲で組織の回復が認め られ，そして何よりも感染の危険性を少なくしたほうが好 都合である.

また, 4 の近心付近の骨の再生もX線的に認められたが, 原因を除去したためによるものなのか, あるいは骨移植に よって骨伝導的なものが関与したのかは判断できないが, それらの骨の機能性, 予知性に関しては研究が待たれると ころである。

\section{まとめ}

（1）将来，インプラント埋入の予定がある場合や，より 多くの組織を増大させるためには, 目的に応じた骨の 量が必要とされる.

（2）ボーングラフトを行うには，それなりの角化組織が 必要である。

（3）オトガイ部は口腔内で大量の自家骨を採取するのに 有効な場所である.

（4）長時間の手術などの場合, 静脈内鎮静法を併用する ことで, 患者の肉体的・精神的苦痛を軽減することが できた。

（5）外科処置は 3 回以上必要となるため, インフォーム ドコンセントの確立が重要であると思われた.

稿を終えるにあたり，ご指導，校閲を賜った南清和先生， 河原英雄先生ほか, そして医療人である前に良質な社会人 でありなさいと歯科医療の基礎の基礎を教えていただいた PDI 埼玉歯科診療所スタッフの皆様, 本稿の執筆の機会を 与えていただいた宮田隆教授に深謝の意を表します。
参考文献

1) Cohen, H.V. : Localized ridge augmentation with hydroxyapatite : Report of case. J. Am. Dent. Assoc., 54 : 108, 1983.

2) Langer, B., Calagna, L.J. : The Subepithelial connective tissue graft. A new approach to the enhancement of anterior cosmetics. Int. J. Perio. Rest. Dent., 3 : 23-34, 1982.

3) Langer, B., Calagna, L.J. : The Subepithelial connective tissue graft. J. Prosthet. Dent., 44 : 363-367, 1980.

4) Garber, D.A., Rosenberg, E.S. : The edenturous ridge in fixed prosthodontics. Compend. Cont. Ed. Gem. Dent., 2 : 212-224, 1981.

5) Abrams, L. : Augmentation of the deformed residual edentulous ridge for fixed prosthesis. Compend. Cont. Ed. Gem. Dent., $1: 205-214,1980$.

6) Schart, D.R., Tarnow, D.P. : Modified roll technique for localized alveolar ridge augmentation. Int. J. Perio. Rest. Dent., 12 : 415-425, 1992.

7) Buser, D., et al. : Localized ridge augmentation gusing guided bone regeneration. Buser, D., Dahlin, C. and Schenk, R.K., Guided bone regeneration in implant dentistry. 1st ed. : 198233, Quintessence Publishing Co. Inc. (St. Louis), 1994.

8) Bahat, O., Fontanesi, R.V. : Soft tissue for optimal placement of osseointegrated implant. Int. J. Perio. Rest. Dent., 13 : 7183, 1993.

9) Buser, D., Dahlin, C., Schenk, R.K. 編 : GBRの歯科インプ ラントへの応用. 第1版：31-100, クインテッセンス出 版 (東京), 1995.

10）下野正基 監修; 井上 孝, 武田孝之 著：インプラント の病理と臨床. 第1 版：139-154, 日本歯科評論 (東京), 1999.

11）新美 敦, 榎本昭二, 山田了, 中村社綱ほか: 特集一 インプラントのためのグラフトマテリアルの現在．イン プラントロジー, 5(4) : 452-487, 1998.

別刷請求先：西岡智秀 